\title{
Analisis Kualitas Pelayanan Pemberian Santunan Bagi Korban Kecelakaan Lalu Lintas Jalan Raya Pada Kantor PT. Jasa Raharja (Persero) Gunungsitoli Analysis of Quality of Services for Providing Compensation for Road Accident Victims at Gunungsitoli PT. Jasa Raharja (Persero) Office
}

\author{
Septian Jonatan' ${ }^{1}$, Abdul Kadir ${ }^{2}$ \& Nina Siti Salmaniah Siregar ${ }^{3}$ \\ 1) Pasca Sarjana Magister Ilmu Administrasi Publik Universitas Medan Area, Indonesia \\ 2) Program Studi Administrasi Publik, Fakultas Ilmu Sosial dan Ilmu Politik, \\ Universitas Medan Area, Indonesia \\ 3) Program Studi Ilmu Komunikasi, Fakultas Ilmu Sosial dan Ilmu Politik, \\ Universitas Medan Area, Indonesia
} \begin{abstract}
Abstrak
Penelitian ini bertujuan untuk menganalisis Kualitas Pelayanan Pemberian Santunan Bagi Korban Kecelakaan Lalu Lintas Jalan Raya Pada Kantor PT. Jasa Raharja (Persero) Gunungsitoli. Jenis penelitian ini adalah deskriftif dengan pendekatan kualitataif, dengan informan penelitian Kepala Jasa Raharja Gunungsitoli, Humas Jasa Raharja Gunungsitoli, Humas Kepolisian Resort Nias dan Masyarakat/ korban/ ahli waris korban kecelakaan lalu lintas. Dalam penelitian ini dilakukan teknik analisa data yaitu metode deskriptif kualitataif. Hasil penelitian ini menunjukkan bahwa kualitas pelayanan asuransi kecelakaan lalulintas di PT. Jasa Raharja Persero Gunungsitoli, yang dilihat dari 6 (dimensi), yaitu Transparansi, Akuntabilitas, Kondisional, Partisipasi, Kesamaan Hak, dan Keseimbangan Hak dan Kewajiban, secara umum telah berjalan dengan baik sesuai dengan ketentuan dan standar pelayanan yang ada. Dari keenam dimensi tersebut hanya ada satu dimensi yang dinailai masih kurang baik, yaitu kesamaan hak dan kewajiban. Hal ini terlihat dari pelayanan yang diberikan oleh PT. Jasa Raharja (Persero) lebih mendahulukan kecelakaan besar dibanding yang terkena kecelakaan individu.

Kata Kunci: Kualitas Pelayanan, Santunan, Korban Kecelakaan, Lalu Lintas Jalan Raya.
\end{abstract}

\begin{abstract}
This study aims to analyze the Service Quality of Providing Compensation for Victims of Road Traffic Accidents at the Office of PT. Jasa Raharja (Persero) Gunungsitoli. This type of research is descriptive with a qualitative approach, with research informants as Head of Raharja Gunungsitoli Services, Raharja Gunungsitoli Public Relations, Police Resort Public Relations of Nias Resort and the community / victims / heirs of victims of traffic accidents. In this research, a data analysis technique is used, which is a qualitative descriptive method. The results of this study indicate that the quality of traffic accident insurance services at PT. Jasa Raharja Persero Gunungsitoli, which is seen from 6 (dimensions), namely Transparency, Accountability, Conditional, Participation, Equal Rights, and Balance of Rights and Obligations, in general has been running well in accordance with existing provisions and service standards. Of the six dimensions, there is only one dimension that is still considered to be unfavorable, namely equality of rights and obligations. This can be seen from the services provided by PT. Jasa Raharja (Persero) takes precedence over major accidents compared to those affected by individual accidents.
\end{abstract}

Keywords: Service Quality, Compensation, Accident Victims, Road Traffic.

How to Cite: Septian Jonatan, Abdul Kadir, Nina Siti Salmaniah Siregar. Analisis Kualitas Pelayanan Pemberian Santunan Bagi Korban Kecelakaan Lalu Lintas Jalan Raya Pada Kantor PT. Jasa Raharja (Persero) Gunungsitoli. Strukturasi: Jurnal Ilmiah Magister Administrasi Publik, 2 (1) 2020:1-14

*E-mail: septianjonatan@gmail.com

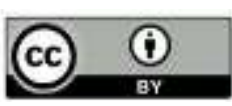




\section{PENDAHULUAN}

Perusahaan yang ingin berkembang dan selalu bertahan harus dapat memberikan kepada para pelanggan produk baik barang maupun jasa yang bermutu lebih baik, harga bersaing, penyerahan lebih cepat, dan pelayanan yang lebih baik dari pada pesaing. Untuk memenuhi kepuasan pelanggan pada industri jasa, kualitas pelayanan penting dikelola perusahaan dengan baik. Dalam hal ini Wyckof dalam Usmara (2003: 230), Kualitas pelayanan merupakan tingkat keunggulan yang diharapkan dan pengendalian atas tingkat keunggulan untuk memenuhi keinginan pelanggan. Menyadari hal tersebut di atas, tampak betapa pentingnya usaha pemahaman akan faktor-faktor yang bisa mempengaruhi kepuasan konsumen dalam pencapaian keberhasilan pemasaran, yaitu: Dimensi tangible atau bukti langsung yang meliputi penampilan gedung, interior bangunan dan penampilan karyawan, dimensi reliability atau kehandalan yang meliputi kemampuan untuk memberikan pelayanan-pelayanan yang terbaik, dimensi responsiveness atau daya tanggap yang meliputi kesediaan karyawan untuk membantu konsumen dan memberikan pelayanan yang cepat, dimensi assurance atau jaminan yang meliputi sopan santun para karyawan dan kemampuan mereka untuk membangkitkan rasa kepercayaan dan rasa percaya konsumen, serta dimensi empathy yang meliputi rasa peduli dan perhatian secara pribadi yang diberikan pada konsumen Tjiptono (2007).

Salah satu bentuk Pelayanan publik yang dilaksanakan oleh pemerintah adalah pemenuhan kebutuhan asuransi masyarakat. Pemerintah melalui Undang-Undang Nomor 33 Tahun 1964 tentang Dana Pertanggungan Wajib Kecelakaan Penumpang dan Undang-Undang Nomor 34 Tahun 1964 tentang Dana Kecelakaan Lalu Lintas Jalan serta Peraturan Menteri Keuangan RI No.16/ PMK.010/ 2017 Tentang Besar Santunan dan Sumbangan Wajib Dana Kecelakaan Lalu Lintas Jalan telah membentuk perusahaan negara yang bergerak dibidang perasuransian yaitu PT. Jasa Raharja. Adapun harapan pembentukan perusahaan perasuransian, agar masyarakat korban dan ahli waris korban kecelakaan lalu lintas memperoleh hak santunan sebagaimana mestinya menurut UndangUndang dan peraturan yang mengatur hal yang dimaksud. Tugas dan tanggung jawab pokok PT. Jasa Raharja adalah memberikan santunan kepada masyarakat yang mengalami kecelakaan lalu lintas sesuai ketentuan Undang-Undang Nomor 33 dan 34 Tahun 1964, dengan cara menghimpun dan mengelolah iuran wajib dari penumpang alat angkutan umum darat, laut dan udara serta sumbangan wajib di Kantor Bersama Samsat dari pemilik kendaran bemotor kepada korban kecelakaan maupun ahli waris korban kecelakaan lalu lintas jalan raya. PT. Jasa Raharja memiliki kantor cabang di setiap provinsi, salah satunya di Sumatera Utara dimana cabang ini memiliki perwakilan dan kantor pelayanan di Daerah Kota/Kabupaten antara lain kantor pelayanan Gunungsitoli. PT. Jasa Raharja kantor pelayanan Gunungsitoli Wilayah mempunyai wilayah kerja meliputi: Kota Gunungsitoli, Kabupaten Nias, Kabupaten Nias Utara dan Kabupaten Nias Barat. Mitra Kerja Jasa Raharja Gunungsitoli yaitu : Polres Nias, BRI Cabang Gunungsitoli, BPPRD Sumatera Utara UPT. Gunungsitoli, dan BPJS Cabang Gunungsitoli.

PT. Jasa Raharja (Persero) merupakan salah satu perusahaan yang bergerak di bidang jasa asuransi sosial. Adanya penurunan kualitas jasa PT. Jasa Raharja selama ini, disebabkan pelayanan Jasa Raharja yang masih belum optimal terkait dengan koordinasi 
dengan pihak kepolisian karena persyaratan untuk proses klaim jaminan sosial yang mengharuskan adanya laporan polisi jika terjadi kecelakaan. Yang kedua adalah sosialisasi ke masyarakat yang belum maksimal karena banyak masyarakat yang tidak mengetahui proses untuk mendapatkan jaminan sosial sehingga terkadang masyarakat beranggapan masih dipersulit oleh pihak Jasa Raharja. Sehubungan dengan fakta tersebut, jika PT. Jasa Raharja tidak dapat meningkatkan pelayanannya dan kalah bersaing dengan perusahaan asuransi lainnya bahkan kepercayaan masyarakat telah berkurang, hal ini akan mengakibatkan munculnya permintaan amandemen atau perubahan Undang-Undang Nomor 33 dan Nomor 34 Tahun 1964. Serta apabila PT. Jasa Raharja tidak mampu meningkatkan kualitas jasanya, perusahaan asuransi sosial milik negara ditutup dan akan dibuka untuk umum.

Kenyataan yang terjadi di lapangan adalah bahwa setiap korban kecelakaan/ahli waris korban kecelakaan lalu lintas jalan raya yang mengajukan klaim santunan asuransi yang tidak selalu memperoleh santunan kecelakaan lalu lintas jalan raya sebagaimana mestinya. Hal tersebut jelas menjadi masalah bagi pemerintahan melalui PT. Jasa Raharja (Persero) dalam menyalurkan santunan asuransi sesuai dengan Undang-Undang Nomor 33 dan 34 Tahun 1964 yang ditetapkan dengan Peraturan Menteri Keuangan RI Nomor 16/ PMK.010/ 2017 Tentang Besar Santunan dan Sumbangan Wajib Dana Kecelakaan Lalu Lintas Jalan. Kenyataan tersebut menunjukan bahwa masih banyak korban kecelakaan lalu lintas jalan raya yang belum mendapatkan haknya untuk memperoleh santunan asuransi kecelakaan jalan raya sesuai dengan Undang-Undang Nomoor 33 dan 34 tahun1964 yang ditetapkanmelalui Peraturan Menteri Keuangan RI Nomor 16/PMK.010/2017. Hal tersebut belum bisa direalisasikan oleh Jasa Raharja, hal ini terlihat dari banyaknya keluhan serta laporan dari masyarakat yang melakukan klaim asuransi di instansi.

Pemberian pelayanan dalam bidang asuransi yang dimaksud dapat mengurangi resiko maupun kejadian kecelakaan, maka PT. Jasa Raharja bisa melakukan kerjasama dengan pihak kepolisian maupun pemerintahan dan masyarakat. Sebagai salah satu instansi pemerintahan PT. Jasa Raharja Gunungsitoli adalah instansi yang bertanggung jawab memberikan pelayanan dalam bidang transportasi termasuk dalam pengurusan pelayanan asuransi sehingga harus memperhatikan setiap pelayanan yang diberikan kepada masyarakat dengan tingkat kualitas yang baik dan memuaskan.

\section{METODE PENELITIAN}

Metode yang digunakan dalam penelitian ini adalah metode deskriftif dengan pendekatan kualitatif, yaitu menghasilkan penelitian dengan menggunakan kata-kata dan berdasarkan hasil yang diperoleh dilapangan. Dengan metode ini diharapkan penulis memperoleh hasil penelitian secara obyektif.

Jenis dan sumber data yang digunakan dalam penelitian ini adalah : Data primer dan data sekunder. Teknik pengumpulan data dilakukan dengan cara observasi, wawancara dan studi pustaka. Analisis data dilakukan dengan mengorganisasikan data, menjabarkan kedalam unit-unit, melakukan sintesa, menyusun ke dalam pola, memilih mana yang penting dan yang akan dipelajari, dan membuat kesimpulan yang dapat 
diceritakan kepada orang lain. Teknik analisis data yang digunakan dalam penelitian ini adalah analisis non-statistik, yaitu berdasarkan hasil observasi, wawancara, dan data dokumentasi terhadap informan yang berkaitan dengan analisis Pelayanan Publik pada PT. Jasa Raharja Kota Gunungsitoli, yaitu analisis data yang berpangkal dari kenyataankenyataan kasus sehingga nantinya akan menghasilkan kesimpulan.

\section{HASIL DAN PEMBAHASAN}

\section{Analisis Kualitas Pelayanan Publik pada PT. Jasa Raharja (Persero)Gunungsitoli}

Kualitas pelayanan merupakan suatu kegiatan pemenuhan kebutuhan keinginan masyarakat serta tingkat keunggulan untuk memenuhi harapan masyarakat terhadap pelayanan yang diberikan oleh PT. Jasa Raharja (Persero) Gunungsitoli dalam melayani asuransi kecelakaan lalulintas. Kualitas pelayanan yang baik, maka pada akhirnya timbul kesesuaian antara harapan masyarakat dengan kinerja yang dirasakan oleh pegawai PT. Jasa Raharja (Persero) Gunungsitoli. Pelayanan yang baik merupakan suatu harapan setiap orang yang berurusan dengan badan atau instansi yang memiliki tugas melayani masyarakat.

Transparansi Pelayanan Asuransi Kecelekann Lalu Lintas PT. Jasa Raharja (Persero) Kota Gunungsitoli. Untuk mewujudkan pelayanan asuransi kecelakaan yang transparan, PT. Jasa Raharja (Persero) Gunungsitoli harus terbuka dalam setiap penyelenggaraan pelayanan asuransi kecelakaan yang dijalankan. Ketranparansian merupakan salah satu asas pelayanan publik yang harus dijalankan oleh setiap lembaga pelayanan dan tidak terkecuali PT. Jasa Raharja (Persero) Gunungsitoli itu sendiri. Dengan demikian, PT. Jasa Raharja (Persero) Gunungsitoli harus setransparan mungkin dalam penyelenggaraan asuransi kecelakaan lalu lintas yang dijalankan, diwujudkan dalam bentuk menginformasikan segala bentuk informasi pelayanan asuransi yang memang menjadi hak klaim asuransi tersebut, secara memadai dan terinci. Ketranparansian pelayanan asuransi kecelakaan lalulintas di PT. Jasa Raharja (Persero) Gunungsitoli perlu dilakukan dengan maksud untuk terwujudnya penyelenggaraan pelayanan pemerintahan yang baik kepada publik. Dengan transparansinya penyelenggaraan pelayanan asuransi kecelakaan yang dijalankan oleh PT. Jasa Raharja (Persero) Gunungsitoli, maka akan memberikan kemudahan kepada masyarakat untuk menilai sejauh mana kualitas pelayanan yang diselenggarakan oleh PT. Jasa Raharja (Persero) Gunungsitoli tersebut.

\section{Informasi Asuransi Kecelakaan Lalulintas di PT. Jasa Raharja (Persero) Gunungsitoli.}

Informasi adalah data yang diolah menjadi bentuk yang berguna untuk membuat keputusan. Penginformasian atau penyebarluasan merupakan suatu tindakan menyampaikan sejumlah keterangan-keterangan kepada individu atau kelompok yang dituju dengan maksud agar keterangan tersebut dapat sampai dan diketahui oleh individu atau kelompok yang dituju. Pengertian Informasi menyangkut asuransi kecelakaan, di sini adalah segala sesuatu yang bersangkutan dengan prosedur yang diberitahukan atau disampaikan oleh pegawai PT. Jasa Raharja (Persero) Gunungsitoli kepada masyarakat umum dalam proses asuransi kecelakaan lalulintas di jalan raya. 
Suatu pelayanan pada dasarnya melibatkan dua pihak yang saling berhubungan, yaitu organisasi pemberi pelayanan dalam hal ini yang dimaksud adalah PT. Jasa Raharja (Persero) di satu pihak dan masyarakat sebagai penerima pelayanan di pihak lainnya. Jika organisasi mampu memberikan pelayanan yang optimal dan memenuhi tuntutan dari masyarakat, maka dapat dikatakan organisasi tersebut telah mampu memberikan pelayanan yang prima pada masyarakat. Oleh karena itu PT. Jasa Raharja (Persero) harus jeli dalam memenuhi kebutuhan masyarakat.

Berdasarkan hasil wawancara dengan Humas PT. Jasa Raharja (Persero) Gunungsitoli melakukan penginformasian atau penyebarluasan mengenai pelayanan asuransi kecelakaan lalulintas yang dijalankan kepada masyarakat dengan berbagai cara, melalui website www.jasaraharja.co.id, brosur, media elektronik serta dialog publik. Dengan demikian, masyarakat yang berhak mendapatkan asuransi kecelakaan lalulintas yang sesuai dengan Undang-undang Nomor 33\&34 Tahun 1964 sebagai stakeholders, akan mengetahui informasi seputar pelayanan asuransi kecelakaan lalulintas yang ada, dan dijalankan oleh PT. Jasa Raharja (Persero) Gunungsitoli. Kemudian, masih terkait masalah ketranparansian informasi. Kemudahan mendapatkan informasi mengenai prosedural dan persyaratan merupakan bentuk dari ketranparansian pelayanan asuransi kecelakaan lalulintas selanjutnya. Berdasarkan wawancara yang dilakukan dengan masyarakat, bahwa informasi mengenai pelayanan asuransi kecelakaan lalulintas di PT. Jasa Raharja (Persero) Gunungsitoli didapat dengan sangat mudah.

Berdasarkan wawancara dengan pemohon klaim asurani kecelakaan lalulintas, disimpulkan bahwa informasi pelayanan asuransi kecelakaan laulintas di PT. Jasa Raharja (Persero) Gunungsitoli didapatkan dengan mudah, karena dengan informasi yang di berikan melalui media-media yang di lakukan PT. Jasa Raharja (Persero) Gunungsitoli mempermudah masyarakat dalam pengajuan asuransi tersebut, sehingga masyarakat mengetahui informasi yang di berikan oleh PT. Jasa Raharja Kota Gunungsitoli tersebut.

Berdasarkan pengamatan peneliti mengenai website www.jasaraharja.co.id, sebagai salah satu sarana atau media penginformasian dan penyebarluasan informasi pelayanan asuransi kecelakaan lalulintas di PT. Jasa Raharja (Persero) Gunungsitoli, masih dirasakan kurang dalam pemberian informasi. Hal itu disebabkan, karena informasi yang disediakan website: www.jasaraharja.co.id, hanya menginformasikan mengenai profil Jasa Raharja secara menyeluruh, sehingga untuk informasi yang berada di wilayah Kota Gunungsitoli belum tersampaikan, seperti alamat perwakilan yang ada di Kota Gunungsitoli tidak di cantumkan, sehingga masyarakat hanya mengetahui alamat perwakilan Sumatera Utara bila melihat informasi dari website tersebut. Kebenaran informasi merupakan sesuatu yang benar-benar dibutuhkan dan diinginkan oleh segenap masyarakat umum, terutama mengenai pelayanan asuransi kecelakaan selaku tugas bagi PT. Jasa Raharja (Persero) Gunungsitoli, oleh karena itu dalam pelaksanaan pelayanan asuransi kecelakaan lalulintas segenap pegawai PT. Jasa Raharja Persro Perwakilan harus memberikan informasi yang sebaik mungkin, sehingga masyarakat bisa merasakan kepuasan tehadap pelayanan asuransi kecelakaan lalulintas tersebut sesuai dengan moto yang dimiliki oleh PT. Jasa Raharja (Persero) yaitu Utama dalam 
pelayan dan Prima dalam Pelayanan",maka pegawai PT. Jasa Raharja (Persero) harus lebih proaktif dalam memberikan pelayanan kepada masyarakat.

Berdasarkan uraian di atas pegawai PT. Jasa Raharja (Persero) Gunungsitoli dalam memberikan informasi pembayaran dana santunan kepada masyarakat di Wilayah Kota Gunungsitoli sudah cukup baik, dimana informasi yang dilakukan oleh pegawai PT. Jasa Raharja (Persero) Gunungsitoli melalui media elektronik, brosur dan dialog publik sangat membatu bagi masyarakat di Wilayah Kota Gunungsitoli mengenai pembayaran dana santunan kecelakaan kekurangan informasinya hanya informasi yang ada di media internet untuk lebih di maksimalkan dalam pemberian informasi tersebut, sehingga bisa lebih baik lagi dalam pemberian informasi sesuai dengan tuntutan tekhnologi. Informasi yang di lakukan oleh pegawai PT. Jasa Raharja (Persero)Kota Gunungsitoli melalui media elektronik, brosur dan dialog publik yang dirasakan cukup di mengerti oleh masyarakat Kota Gunungsitoli.

\section{Akuntabilitas Pelayanan Asuransi Kecelakaan Lalulintas di PT. Jasa Raharja (Persero) Gunungsitoli.}

Akuntabilitas, yaitu pelayanan yang dapat dipertanggung jawabkan sesuai dengan aturan perundang- undangan. Penyelanggaraan pelayanan publik yang baik adalah penyelanggaraan publik yang bertanggungjawab kepada publik itu sendiri atas apa yang mereka lakukan kepada publik, khusunya dalam hal ini dalam hal pelayanan itu sendiri. Pertanggung jawaban itu dilakukan kepada masyarakat sebagai penerima layanan, dan kepada atasannya sebagai laporan pertanggung jawaban. Akuntabilitas, yaitu pelayanan yang dapat dipertanggung jawabkan sesuai dengan aturan perundang- undangan. Penyelanggaraan pelayanan publik yang baik adalah penyelanggaraan publik yang bertanggungjawab kepada publik itu sendiri atas apa yang mereka lakukan kepada publik, khusunya dalam hal ini dalam hal pelayanan itu sendiri. Pertanggung jawaban itu dilakukan kepada masyarakat sebagai penerima layanan, dan kepada atasannya sebagai laporan pertanggung jawaban.

\section{Fiscal Accountability Pelayanan Asuransi Kecelakaan Lalulintas di PT. Jasa Raharja (Persero) Gunungsitoli}

Berdasarkan hasil wawancara, PT. Jasa Raharja (Persero) Gunungsitoli melakukan pertanggung jawaban keuangan kepada PT. Jasa Raharja (Persero) Perwakilan Sumatera Utara, dan PT. Jasa Raharja (Persero) Pusat selaku atasannya dan juga ke Menteri Keuangan Republik Indonesia, serta ke Menteri Badan Usaha milik Negara, laporan atau publikasi anggaran penyelenggaraan asuransi kecelakaan lalulintas kepada masyarakat yang pada umumnya dilakukan melalui media dilakukan oleh PT. Jasa Raharja (Persero) Pusat seperti yang terlihat pada gambar berikut ini mengenai laporan keuangan.

Berdasarkan hasil uraian di atas, Fiscal Accountability pelayanan Asuransi kecelakaan lalulintas di PT. Jasa Raharja Persro Kota Gunungsitoli, menurut hasil uraian di atas dapat dikatakan cukup baik. Hal itu dilihat dari terencananya setiap penggunaan untuk kegiatan dan program yang ada, serta dilakukannya kewajiban untuk melakukan pertanggung jawaban keungan kepada yang berwenang ke perwakilan Sumatera Utara 
dan Pemerintah Pusat selaku atasannya. Dengan begitu masyarakat juga dapat berpartisipasi dalam pelayanan asuransi kecelakaan lalulintas di PT. Jasa Raharja (Persero), baik berupa saran dan kritik maupun bantuan materi.

\section{Legal Accountability Pelayanan Asuransi Kecelakaan lalulintas di PT. Jasa Raharja (Persero) Gunungsitoli}

Nilai santunan memiliki kriteria yang telah ditetapkan berdasarkan Surat Keputusan Menteri Keuangan RI Undang-Undang No. 33 \& 34 Tahun 1964 (berdasarkan Kepmen Keu. No. 415/KMK. 06/2001 Sehingga korban kecelakaan sudah mendapatkan haknya dari pembayaran yang telah dilakukan yaitu membayar Iuran Wajib Dana Pertanggungan Kecelakaan Penumpang (IWDPKP). Undang-Undang No 33\&34 Tahun 1964 adalah aturan pokok yang mengatur tugasdan fungsi PT. Jasa Raharja (Persero) Gunungsitoli, yang menjadi landasan beserta dasar dalam penyelenggaraan asuransi kecelakaan.

Untuk mengetahui apakah PT. Jasa Raharja (Persero) Gunungsitoli telah menjalankan tugas dan fungsinya sesuai dengan fungsi yang ada, Berdasarkan hasil wawancara, PT. Jasa Raharja (Persero) Gunungsitoli dalam pelayanan asuransi kecelakaan lalulintas selalu berpegang teguh pada aturan yang ada. Semua aturanaturan yang terkait selalu diperhatikan dan dijalankan dengan baik, sehingga masyarakat bisa merasakan terhadap tugas yang di berikan oleh pemerintah dalam melayani asuransi kecelakaan tesebut Berdasarkan uraian yang dikemukakan oleh pegawai PT. Jasa Raharja (Persero) Gunungsitoli di atas, legal accountability atau pertanggung jawab secara legal atas penyelenggaraan pelayanan asuransi kecelakaan lalulintas di PT. Jasa Raharja (Persero) Gunungsitoli dikatakan baik. Hal itu dilihat dari sudah dipatuhinya Peraturan Undang-undang Nomor 33\&34 Tahun 1964 tentang aturan pokok yang mengatur tugasdan fungsi PT sJasa Raharja (Persero) Kota Gunungsitoli, yang menjadi landasan beserta dasar dalam penyelenggaraan asuransi kecelakaan.

\section{Proses Accountability Pelayanan Asuransi Kecelakaan Lalulintas di PT. Jasa Raharja (Persero) Gunungsitoli}

Process accountability pelayanan asuransi kecelakaan lalulintas di PT. Jasa Raharja (Persero) Gunungsitoli dirasakan cukup baik, hal itu dilihat dari Sumber Daya Pegawai dan Sumberdaya Sarana dan Pasarana yang dimiliki sudah mampu melakanakan pelayanan asuransi kecelakaan lalulintas kepada klaim asuransi dengan cukup baik.Pendidikan dan pelatihan yang dilakukan oleh PT. Jasa Raharja (Persero) terhadap para pegawainya harus dilakukan secara terus menerus, karena pendidikan dan pelatihan merupakan salah satu upaya untuk pengembangan SDM yang ada di PT. Jasa Raharja (Persero). Hal ini dilakukan karenaPT. Jasa Raharja (Persero) bergerak di bidang asuransi sosial yang langsungberhubungan dengan masyarakat sehingga membutuhkan pelayanan berkualitas yangbaik dalam proses pemberian pelayanan kepada masyarakat. 


\section{Outcome Accountability Pelayanan Asuransi kecelakaan lalulintas di PT. Jasa Raharja (Persero) Gunungsitoli}

Dari hasil wawancara, upaya yang dilakukan oleh pegawai PT. Jasa Raharja (Persero) Gunungsitoli, memberikan suatu pelayanan yang langsung berinteraksi dengan masyarakat.seperti ketika terjadi kecelakaan yang menimpa terhadap masyarakat, korban yang mengalami kecelakaan tersebut di bantu langsung dengan turun tanganya pihak PT. Jasa Raharja (Persero) Gunungsitoli dalam pengurusan klaim asuransi tersebut, Dengan demikian, manfaat yang diberikan dapat dirasakan langsung oleh masyarakat, karena masyarakat membutuhkan dana dalam kecelakaan yang meninpanya asalkan sesuai dengan undang undang Nomor 34 Tahun 1964 tersebut. PT. Jasa Raharja (Persero) Gunungsitoli memberikan pelayanan dengan sebaik mungkin dalam pelayanan asuransi tersebut,karena masyarakat yang mengalami kecelakaan lalulintas tersebutsangat membutuhkan biaya untuk keperluan pengobatan maupun biaya pemakaman. Maka dari itu PT. Jasa Raharja (Persero) selalu memperhatikan masyarakat korban kecelakaan yang terlindungi dalam Undang-undang tersebut agar bisa merasakan manfaat asuransi kecelakaan lalulintas.

Dari hasil wawancara yang dilakukan oleh peneliti, manfaat pelayanan yang diberikan oleh PT. Jasa Raharja (Persero) Gunungsitoli sudah dirasakan langsung oleh masyarakat yang mengalami kecelakaan yang terlindung dalam Undang-undang Nomor 34 Tahun 1964, dengan adanya asuransi kecelakaan lalulintas yang di berikan oleh PT. Jasa Raharja tersebut, masyarakat mendapat perlindungan terhadap kerugian yang diderita karena risiko-risiko tersebut oleh Negara. Khususnya risiko yang diakibatkan dari kecelakaan lalu lintas, yang dewasa ini semakin meningkat.Karena semakin sengitnya persaingan dibidang ekonomi masyarakat lupa memperhatikan risiko yang bakal timbul kemudian.

Outcome accountability pelayanan asuransi kecelakaan lalulintas di PT. Jasa Raharja (Persero) Gunungsitoli dinilai baik, hal itu dilihat dari tercapainya tujuan dari pelayanan rasuransi kecelakaan lalulintas yang ada, yaitu mengembalikan fungsi sosial korban kecelakaan lalulintas yang terlindungi dalam Undang-Undang Nomer 34 Tahun 1964 , sehingga masyarakat terlindungi oleh negara yang di akibatkan dari kecelakaan lalulintas tersebut. PT. Jasa Raharja (Persero) Gunungsitoli telah membantu korban kecelakana bagi masyarakat, hal itu tidak luput dari keseriusan serta upaya yang dilakukan oleh par pegawai PT. Jasa Raharja (Persero) Gunungsitoli dalam memberikan perlayanan yang berkualitas bagi masayarakat.

\section{Kondisional Dalam Pelayanan asuransi Kecelakaan Lalulintas Di PT. Jasa Raharja (Persero) Gunungsitoli}

Berdasarkan hasil wawancara dengan Kepala Cabang PT. Jasa Raharja (Persero) Gunungsitoli efektifitas dalam pelayanan asuransi terlihat dalam pelayanan secara teknis oleh petugas berjalan dengan lancar dan tidak berbelitbelit. Pelayanan yang baik dan benar sangat mendukung terhadap pengefektifan waktu yang dilakukan menjadikan pelayanan yang berkualitas sesuai yang diharapkan oleh para pemohon klaim asuransi kecelakaan lalulintas. Petugas membatasi pelayanan dengan memberikan pelayanan 
sesuai dengan prosedur serta hanya dalam konteks hal yang dilayani dan para petugas tidak melayani kepentingan lain di luar konteks pelayanan asuransi. Namun pelayanan asuransi kecelakaan lalulintas di PT. Jasa Raharja (Persero) Gunungsitoli menyangkut seberapa lama waktu yang dibutuhkan untuk menyelesaikan suatu pelayanan yang diberikan kepada satu orang, menurut peneliti belum maksimal,berdasarkan hasil wawancara dengan masyarakat pelayanan asuransi sampai cairnya dana asuransi tersebut memakan waktu 3 minggu bahkan sampai 1 bulan lamanya.

\section{Parsitipatif Dan Kerja Sama Masyarakat dalam Pelayanan asuransi kecelakaan lalulintas di PT. Jasa Raharja (Persero) Gunungsitoli.}

Sistem pengelolaan pengaduan dapat digunakan masyarakat melalui fasilitas saran dan komentar. Partisipatif dalam Pelayanan asuransi kecelakaan lalulintas di PT. Jasa Raharja (Persero) Gunungsitoli. Partisipatif dengan komunikasi yang sinergis antara pegawai PT. Jasa Raharja (Persero) Gunungsitoli dan pemohon klaim asuransi kecelakaan. Pegawai dan pemohon klaim asuransi kecelakaan lalulintas saling membantu, memperlancar lagi proses klaim asuransi kecelakaan lalulintas, memberi masukan terhadap kekurangan dalam proses pelayanan asuransi kecelakaan lalulintas tersebut.

Menurut keterangan Pelaksana Administrasi PT. Jasa Raharja (Persero) Gunungsitoli, untuk mengolah berbagai pengaduan masyarakat menjadi bahan masukan untuk perbaikan pelayanan publik. Tuntutan masyarakat terhadap pelayanan yang baik semakin menguat. Komunikasi yang dilakuakan dapat berupa suatu sosialisasi terhadap masyarakat baik itu secara langsung maupun tidak langsung, hal tersebut perlu untuk dilaksanakan karena bagaimanapun masyarakat merupakan penerima pelayanan dari pelaksanaan kegiatan pelayanan asuransi kecelakaan lalulintas. Perlunya sosialisasi terhadap masyarakat menyangkut asuransi kecelakaan, telah di pahami oleh PT. Jasa Raharja (Persero) Gunungsitoli, dengan mendirikan papan-papan himbauan yang dipasang dibeberapa titik disekitar PT. Jasa Raharja (Persero) Gunungsitoli dan tempattempat vital lainya di Kota Gunungsitoli, sesuai dengan observasi yang dilakuakn oleh peneliti. Namun sosialisai tersebut tentunya tidak akan berjalan, bilamana masyarakat Kota Gunungsitoli (sebagai pengaju klaim asuransi kecelakaan lalulintas), tidak dapat bekerjasama dengan PT. Jasa Raharja (Persero) Gunungsitoli menyangkut pelaksanaan asuransi kecelakaan lalulintas tersebut.

\section{Harapan Dalam Pelayanan Asuransi Kecelakaan Lalulintas di PT. Jasa Raharja (Persero) Gunungsitoli.}

Ada beberapa penyebab utama tidak terpenuhinya harapan pelanggan, penyebab tersebut ada yang bias dikendalikan oleh penyedia jasa. Dengan demikian, penyedia jasa bertanggung jawab untuk meminimunkan miskomunikasi yang mungkin terjadi. Ada beberapa faktor yang mempengaruhi seorang yang secara umum tingkat kepuasan individu asuransi kecelakaan lalu lintas, berdasarkan hasil pengamatan dilapangan terdapat ketidak sejajaran antara harapan dan pelayanan yang didapat oleh pemohon. Hal ini dapat dilihat dari lebih kecilnya persentasi pencapaian dari pada harapan yang 
mereka inginkan karena kualitas pelayanan memiliki pengaruh terhadap kepuasan masyarakat yang mendapatkan pelayanan tersebut.

Data yang peneliti peroleh dari informan yang peneliti wawancarai memaparkan bahwa harapan yang diinginkannya menyangkut pelayanan asuransi kecelakaan lalulintas di PT. Jasa Raharja (Persero) Gunungsitoli belum terpenuhi, yang disebabkan masih lamanya proses pelayanan klaim asuransi kecelakaan lalulintas yang memakan waktu tiga hingga empat minggu. Sesuai dengan apa yang peneliti sampaikan sebelumnya lamanya pembayaran klaim asuransi kecelakaan lalulintas karena masih kurangnya pemahaman masyarakat tentang persyaratan yang harus dilakukan dalam pengajuan. PT. Jasa Raharja (Persero) Gunungsitoli dalam memberikan pelayanan asuransi kecelakaan lalulintas perlu lebih mensosialisasikan kembali kepada masyarakat mengenai berbagai macam keunggulan dan prosedur yang perlu untuk dipenuhi oleh masyarakat dalam asuransi kecelakaan lalulintas karena masih banyak masyarakat yang belum mengetahui prosedur pelayanan asuransi tersebut.

\section{Kesamaan Hak Pelayanan asuransi kecelakaan lalulintas di PT. Jasa Raharja (Persero) Gunungsitoli}

Prilaku teguh dan tegas pegawai harus berpegang teguh pada ketiga hal tersebut, yaitu prinsip, aturan dan moral dalam memberikan pelayanan. Dengan demikian, keteguhan dan ketegasan pegawai yang baik adalah keteguhan dan ketegasan yang harus berpegang pada prinsip, aturan dan moral pelayanan. Kesamaan hak pelayanan asuransi kecelakaan lalulintas di PT. Jasa Raharja (Persero) Gunungsitoli dapat dikatakan baik. Hal itu dilihat dari keteguhan dan ketegasan pegawai dalam memberikan pelayanan asuransi kecelakaan lalulintas. Keteguhan dan ketegasan itu diwujudkan oleh pegawai PT. Jasa Raharja (Persero) Gunungsitoli dalam prilaku yang tidak membedabedakan, memegang prinsip yang telah disepakati yaitu selalu siap untuk memberikan pelayanan kepada klaim asuransi kapanpun membutuhkan. Sikap yang hangat dan ramah juga ditunjukan oleh pegawai PT. Jasa Raharja (Persero) Gunungsitoli. Penjelasan mengenai keteguhandan ketegasan pegawai di PT. Jasa Raharja (Persero) Gunungsitoli akan dijabarkan pada bagian dibawah ini:

Dari hasil wawancara, sikap yang diberikan dalam memberikan pelayanan dalam hal menanggapi keluhan dari masyarakat selalu berpegang pada prinsip dan etika pelayanan yang ada, pegawai PT. Jasa Raharja (Persero) Gunungsitoli selalu memahami latar belakang pemohon klaim asuransiyang menyampaikan keluhan terhadap hal dalam proses pelayanan asuransi.bahasa yang digunakan oleh masyarakat tersebut dalam menyampaikan keluhan, hal itu dikarenakan oleh latar belakang yang berbeda dari setiap masyarakat. Pegawai PT. Jasa Raharja (Persero) Gunungsitoli menanggapi keluhan dari para pemohon klaim asuransi dengan bahasa yang mudah dimengerti dan dapat dipahami dengan mudah, hal itu bertujuan agar informasi yang disampaikan kepada masyarakat dapat diterima dengan baik, dan di pahami. Hal itu sejalan dengan pernyataan salah satu masyarakat yang mengajukan klaim asuransi pelayanan asuransi kecelakaan lalulintas tentang sikap dari pegawai PT. Jasa Raharja (Persero) Gunungsitoli mengatakan, bahwa. "keluhan dalam mengajukan asuransi yang diajukan ditanggapi 
dengan baik serta tanggapan yang diberikan mudah dimengerti dan ditanggapi dengan cepat" Dari hasil wawancara diatas, masyarakat sudah mendapatkan kepuasan mengenai sikap yang diberikan kepada masayarakat pengaju klaim asuransi, hal itu ditunjukan dengan tanggapan yang diberikan kepada masyarakat yang mengajukan klaim asuransi selalu direspon dengan baik, dan cepat oleh pegawai PT. Jasa Raharja (Persero) Gunungsitoli.

Keteguhan pegawai PT. Jasa Raharja (Persero) Gunungsitoli dinilai sudah cukup baik, hal itu dinilai dari sikap pegawai yang menanggapi keluhan pengajuan dari setiap masyarakat yang mengajukan klaim asuransi dengan cepat dan memuaskan serta mudah di mengerti, pegawai PT. Jasa Raharja (Persero) Gunungsitoli juga berupaya memahami latar belakang dari masyarakat. Hal itu dilakukan agar jawaban yang diberikan kepada masyarakat yang mengajukan klaim asuransi dapat diterima dengan baik

\section{Ketegasan Pegawai Pelayanan Asuransi Kecelakaan Lalulintas di PT. Jasa Raharja (Persero) Gunungsitoli}

Hal itu sesuai dengan hasil wawancara dengan pegawai penanggung jawab pelayanan PT. Jasa Raharja (Persero) Gunungsitoli mengenai Bentuk ketegasan pegawai PT. Jasa Raharja (Persero) melakukan pengecualian-pengecualian kepada korban dalam pemberian santunan Asuransi Kecelakaan Lalu Lintas Berdasarkan hasil wawancara pegawai PT. Jasa Raharja (Persero) Gunungsitoli tidak melakukan perbedaan perlakuan dalam memberi pelayanan kepada masyarakat dalam pemberian jaminan dana santunan asuransi kecelakaan. Pegawai PT. Jasa Raharja (Persero) Gunungsitoli tidak memandang status, semua mendapatkan pelayanan yang sama. Hal itu dilakuakan karna perlakuan yang sama merupakan suatau kewajiban yang harus dilakukan sesuai dengan prinsip pelayanan yang baik dan sesuai denganperaturan Undang-Undang yang di jalaninya.

Dari hasil wawancara, pegawai PT. Jasa Raharja (Persero) Gunungsitoli menberikan pelayanan yang baik dan harus semestinya, hal itu ditunjukan bahwa, tidak ada perbedaan perlakuan yang diberikan, selama hal yang diajukan masih sesuai dengan permasalahan kecelakaan sesuai dengan pelayanan untuk pemberian dana santunan asuransi kecelakaan lalulintas tersebut, penerima klaim asuransi selalu mendapatkan perlakuan yang baik dari pegawai PT. Jasa Raharja (Persero) Gunungsitoli. Ketegasan pegawai PT. Jasa Raharja (Persero) Gunungsitoli dalam memberikan pelayanan dinilai baik, hal ini dilihat dariketegasan pihak PT. Jasa Raharja (Persero) terhadap pemberian dana asuransi kecelakaan lalu lintas yanpa pandang bulu. Perlakuan yang tegas merupakan keharusan sikap yang harus ditunjukan oleh pegawai PT. Jasa Raharja (Persero) Gunungsitoli. Namun, perlakuan yang tegas bukan perlakuan yang tidak wajar dan semena-mena.

\section{Kejujuran dalam Pelayanan asuransi Kecelakaan Lalulintas di PT. Jasa Raharja (Persero) Gunungsitoli}

Kejujuran menciptakan pelaksanaan tugas dianggap sebagai ibadah bukan sebagai beban. Kejujuran sebagai nilai etik yang fundamental ditandai dengan sikap terbuka sebagian pegawai PT. Jasa Raharja (Persero) Gunungsitoli yang tidak pernah 
menutup-nutupi dalam memberikan pelayanan kepada masyarakat. Pegawai PT. Jasa Raharja (Persero) Gunungsitoli bersedia mengungkapkan sesuatu yang menjadi perhatian masyarakat mengenai pelayanan asuransi kecelakaan lalulintas tersebut. Sebagian pegawai PT. Jasa Raharja (Persero) Gunungsitoli tidak mempunyai vested interest (kepentingan sendiri) karena mengganggu kelancaran dan keberhasilan pekerjaan. Oleh karena itu mereka juga mampu menghindar dari kepentingan sendiri antara tanggung jawab sebagai pemberi pelayanan dengan segala bentuk keinginan dan tuntutan yang bersifat personal. Pegawai yang mampu menghindar dari segala bentuk keinginan yang bersifat personal dikarenakan mereka memegang teguh prinsip bahwa semata - mata menjalankan tugas dan amanah yang ditugaskan oleh pemerintah sesuai dengan undang-undang. Pegawai PT. Jasa Raharja (Persero) Gunungsitoli yang menjalankan tugas dengan jujur, percaya bahwa dengan kejujuran tugas yang dijalankan terasa lebih ringan.

Berdasarkan uraian di atas, kejujuran menciptakan tugas yang dijalankan terasa lebih ringan. Pegawai PT. Jasa Raharja (Persero) Gunungsitoli yang lebih mementingkan kepentingan sendiri dibandingkan dengan kepentingan masyarakat banyak, akan mengurangi kualitas pelayanan asuransi kecelakaan lalulintas. pegawai yang didapati melakukan pelanggaran akan mendapatkan sanksi yang sesuai dengan pelanggaran yang dibuatnya. Dengan seringnya petugas melakukan pelanggaran, maka kepercayaan masyarakat terhadap pelayanan asuransi kecelakaan lalulintas yang diberikan oleh PT. Jasa Raharja (Persero) Gunungsitoli akan berkurang.

\section{SIMPULAN}

Kualitas pelayanan asuransi kecelakaan lalulintas di PT. Jasa Raharja (Persero) Gunungsitoli, yang dilihat dari 6 (dimensi), yaitu transparansi, akuntabilitas, ondisional, partisipasi, kesamaan hak, dan keseimbangan hak dan kewajiban, secara umum telah berjalan dengan baik sesuai dengan ketentuan dan standar pelayanan yang ada. Dari keenam dimensi tersebut hanya ada satu dimensi yang dinailai masih kurang baik, yaitu kesamaan hak dan kewajiban. Tranparansi pelayanan asuransi kecelakaan lalulintas di PT. Jasa Raharja (Persero) Gunungsitoli dinilai sudah cukup baik hal itu dilihat dari keterbukaan data yang diberikan kepada masyarakat, namun dari segi kelengkapan informasi pelayanan asuransi kecelakaan lalulintas masih belum lengkap, seperti pada media website: www.jasaraharja.co.id.

Akuntabilitas pelayanan asuransi kecelakaan lalulintas di PT. Jasa Raharja (Persero) Gunungsitoli sudah dinilai cukup baik, dikarenakan telah terlaksana dengan cukup baik dan cukup optimal karena adanya bukti nyata sebagai penunjang kualitas pelayanan itu sendiri yang telah memenuhi standar pelayanan yang berlaku di PT. Jasa Raharja (Persero) Gunungsitoli.

Kondisional dalam Pelayanan asuransi Kecelakaan Lalulintas Di PT. Jasa Raharja (Persero) Gunungsitoli sudah di nilai cukup baik, hal ini di lihat dari adanya upaya yang dilakukan oleh PT. Jasa Raharja (Persero) Gunungsitoli untuk memberikan pelayanan yang prima melalui pengefektifan, pengefisienan yang didasari kredibiltas, kesigapan, kejujuran serta rasa tangung jawab para pegawai PT. Jasa Raharja (Persero) 
Gunungsitoli serta dalam memberikan pelayanan asuransi kecelakaan lalulintas telah baik. Parsitipatif dan Kerja Sama Masyarakat dalam Pelayanan asuransi kecelakaan lalulintas di PT. Jasa Raharja (Persero) Gunungsitoli. di nilai cukup baik,hal ini di lihat dari adanya peran masyarakat dalam pelayanan asuransi kecelakaan lalulintas di PT. Jasa Raharja (Persero) Gunungsitoli. Peran masyarakat yang sangat partisipatif disebabkan karena baiknya mutu orientasi pada kebutuhan dan harapan masyarakat.

Kesamaan hak pelayanan asuransi kecelakaan lalulintas di PT. Jasa Raharja (Persero) Gunungsitoli dinilai dari keteguhan dan ketegasan pegawai PT. Jasa Raharja (Persero) Gunungsitoli. Keseimbangan hak dan kewajiban di PT. Jasa Raharja(Persero) Kota Gunungsitoli dalam melayani asuransi kecelakaan lalu lintas belum cukup adil.

\section{DAFTAR PUSTAKA}

Anwar, I. (2017). Analisis Pengaruh Kualitas Layanan Terhadap Kepuasan Konsumen Pada Ekspedisi Pt. Sinar Mas Transindo Surabaya. Jurnal Ilmu dan Riset Manajemen Volume 6, Nomor 10, Oktober 2017 ISSN: 2461-0593.

Arie, Permana. (2013). "Kualitas Pelayanan PT. Jasa Raharja (Persero) Cabang Jawa Timur Dalam Memberikan Santunan Asuransi Bagi Korban Kecelakaan Lalu Lintas". http://eprints.upnjatim.ac.id/4919/1/file1.pdf.

B. R, Mishra P. K., \& Shekhar. (2010). Measuring quality of service in retail outlets using fuzzy numbers. Management Science and Engineering, 4(3), 80-86. doi: http://dx.doi.org/10.3968\%2Fj.mse.1913035X20100403.008

Bala, N., Sandhu, H. S., \& Nagpal, N. 2011. Measuring life insurance service: An empirical assessment of servqual instrument. International Business Research, 4(4), 176-190.

Boediono, B. (2003). Pelayanan Prima Perpajakan. Jakarta: Rineka Cipta.

Butt, M. M., \& de Run, E. C. (2010). "Private healthcare quality: applying a SERVQUAL model. International" Journal of Health Care Quality Assurance, 23(7), 658-673.

Desi, Kurniawati dan Putut, Haribowo. (2013).“ Analisis Kepuasan Klaimen Atas Kualitas Pelayanan PT. Jasa Raharja (Persero) Perwakilan Pati”. http://admisibisnis.blogspot.com/2013/07/analisiskepuasan-klaimen-atas-kualitas.html.

Djaenuri, H.M. Aries. (1997). Manajemen Pelayanan Umum. Jakarta: IIP Press

Fitzsimmons, J.A., Mona AF. (1994). Service Management for Competitive Advantage. London: Mc Graw Hill.

Gaspersz, V. (1994), Manajemen Kualitas. Jakarta: Gramedia.

http://rynaldi-dwitama.blogspot.com/2012/05/pengertian-struktur-organisasi.html. diakses pada tanggal 17 April 2019

Ibrahim, Amin. (2008). Teori dan Konsep Pelayanan Publik Serta Implementasinya. Gunungsitoli: Mandar Maju.

J. Supranto. (2007). Pengukuran Tingkat Kepuasan Pelanggan untuk Menaikkan Pangsa Pasar. Jakarta: PT. Renika Cipta.

Kotler, P. (1997). Marketing management. New Jersey: Prentice Hall. Inc

Melda, Ria Yanti, 2017, "Kualitas Pelayanan Publik Pada PT. Jasa Raharja (Persero)Kota Pekabaru”. JOM FISIP Vol. 4 No. 1 - Februari 2017.

Miftah, T. (1995). Perilaku Organisasi Konsep Dasar dan Aplikasinya. Jakarta: Raja Grafindo Persada.

Moenir, H. AS. (2006). Manajemen Pelayanan Umum di Indonesia. Jakarta : Bumi Aksara.

Nasution, S. (1990). Pengertian Belajar. Bandung: Bumi Aksara.

Nawawi, Hadari. (2010). Metode Penelitian Bidang Sosial. Yogyakarta: Gadjah Mada University Press.

Ndraha, Taliziduhu. (2000). Ilmu Pemerintahan (Kybernology). Jakarta : Rineka Cipta.

Nugraha, A. (2014)."Kualitas Pelayanan PT. Jasa Raharja (Persero) Gunungsitoli (Studi Pada Asuransi Kecelakaan Lalu lintas Jalan Raya Kota Gunungsitoli. https://repository.unikom.ac.id/29756/.

Osborne, David \& P. Plastrik. (1997). Banishing Bureaucracy: The Five Strategies for Reinventing Government, New York: Addison-Wesley.

Osborne, David, \& Ted Gaebler. (2012). Reinventing Government: How the Entrepreneurial Spirit is Transforming the Public Sector. New York: Addison-Wesley.

Parasuraman. (2000). Delivering Quality Service. New York: The Free Press. 
Septian Jonatan, Abdul Kadir, Nina Siti Salmaniah Siregar. Analisis Kualitas Pelayanan Pemberian Santunan Bagi Korban Kecelakaan Lalu Lintas Jalan Raya Pada Kantor PT. Jasa Raharja (Persero) Gunungsitoli

Pawitra, Teddy. (1993). Pemasaran: dimensi falsafah, disiplin, dan keahlian. Sekolah Tinggi Manajemen Prasetiya Mulya

Profil PT. Jasa Raharja (Persero), Jakarta

Rangkuti, Freddy. (2003). Measuring Customer Satisfaction, Teknik Mengukur dan Strategi Meningkatkan Kepuasan Pelanggan Plus Analisis Kasus PLN-JP. Jakarta: PT. Gramedia Pustaka Utama.

Rasyid, M. Ryaas. (1997). Kajian Awal Birokrasi Pemerintahan dan Politik Orde Baru. Jakarta: Yarsif Watampone.

Ratminto. (2009), Konsep-konsep Dasar Manajemen Pelayanan, Yogyakarta: Universitas Gadjah Mada.

Sejarah. Y. (2017). http://yes-sejarah.blogspot.com/2017/05/sejarah-perusahaan-pt-jasaraharja.html.Online.Diakses pada tanggal 17 April 2019

Sinambela, L.P. (2010). Reformasi Pelayanan Publik;Teori,Kebijakan dan Implementasi. Jakarta: PT. Bumi Aksara.

Sugiono. (2012). Memahami Penelitian Kualitatif. Bandung: Alfabeta.

Sugiyono, 2012, Metode Penelitian Administratif, Rineka Cipta, Jakarta.

Supranto, 2001, Pengukuran Tingkat Kepuasan : Untuk Menaikkan Pangsa Pasar. Jakarta : Rineka Cipta.

Supriatna, Tjahya, 2006, Administrasi Birokrasi dan Pelayanan Publik. Jakarta : Nimas Multima.

Susiloadi, Priyanto. 2008. Implementasi Corporate Sosial Responsibility untuk Mendukung Pembangunan Berkelanjutan. Spirit Publik.

Tjiptono, F. (1995). Strategi Pemasaran. Yogyakarta : Andi.

Usmara. (2003). Starategi Baru Manajemen Pemasaran. Yogyakarta: Amoro Book.

Utomo, W. (1997). Peranan Dan Starategi Peningkatan dan Pendapatan Asli Daerah (PAD). Jakarta: Pustaka Pelajar

V. W, Ispurwanto W. \& Pricillia. (2011). “Analisis Kepuasan Penumpang Gerbong Kereta Api Khusus Wanita Menggunakan Metode Servqual”. Thesis Program Pascasarjana, Universitas Bina Nusantara.

Widodo, J. (2001). Good Governance: Telaah dari Dimensi: Akuntabilitas dan Kontrol Birokrasi pada Era Desentralisasi dan Otonomi Daerah. Surabaya: Insan Cedekia.

Zeithaml, V. A. (2010). Delivering Quality Services Balancing Customer Perceptions and Expectations

Zeithaml, V.A, (2008). "Servqual: A Multiple-Item Scale for Measuring Consumer Perceptions of Service Quality". Journal of Retailing, Spring.

Peraturan PerUndang-Undangan

Keputusan Menteri Pendayagunaan Pegawai Negara (MENPAN) Nomor 63 Tahun 2003 Tentang Pedoman Umum Pelayanan Publik.

Undang-Undang No.25 Tahun 2009 Tentang Pelayanan Publik

Undang-Undang No.33 Tahun 1964 Tentang Dana Pertanggung Wajib Kecelakaan Penumpang

Undang-Undang No.34 Tahun 1964 Tentang Dana Kecelakaan Lalu Lintas.

Peraturan Menteri Keuangan RI No.15/ PMK.010/ 2017 Tentang Besar Santunan dan Iuran Wajib Dana Pertanggung Wajib Kecelakaan Alat Angkutan Penumpang Umum di Darat, Sungai/ Danau, Ferry/ Penyebrangan, Laut dan Udara

Peraturan Menteri Keuangan RI No.16/ PMK.010/ 2017 Tentang Besar Santunan dan Sumbangan Wajib Dana Kecelakaan Lalu Lintas Jalan

Peraturan Pemerintah No.17 Tahun 1965 Tentang Ketentuan Pelaksanaan Iuran Wajib Kecelakaan Penumpang

Peraturan Pemerintah No.18 Tahun 1965 Tentang Ketentuan Pelaksanaan Dana Kecelakaan Lalu Lintas Jalan. 